\title{
'BETTER A WITTY FOOL THAN A FOOLISH WIT': ON PUNNING STYLES OF SHAKESPEARE'S PEDANTS AND JESTERS ${ }^{1}$
}

\author{
Magdalena AdAMCZyK \\ University of Zielona Góra, Poland
}

\begin{abstract}
One of the hallmarks of Shakespeare's stylistic uniqueness is undoubtedly his dexterous use of puns. Besides being skilfully woven into the dramatic texture of his plays, their great strength lies also in the fact that they are carefully tailored to cater for both dramatic and conversational needs of individual characters. The paper attempts to zoom in on two distinctive punning styles of Shakespeare's dramatis personae, as developed by pedants (here represented by Holofernes from Love's Labour's Lost) and jesters (exemplified by Feste from Twelfth Night). By way of examining the peculiarities of their punning in terms of its amount, semantics, conversational dynamics and participant configuration, the study demonstrates that the two figures represent the opposite poles of the punning art. Whereas the jester proves a virtuoso punster trading witty repartees whenever opportunity offers, the pedant's puns, being overly sophisticated and erudite, appear highly impenetrable and flat in effect.
\end{abstract}

Keywords: Pun, wordplay, Elizabethan English, Shakespeare's comedy, jester, pedant.

\footnotetext{
1 The author wishes to express her deep gratitude to the anonymous reviewers for their insights and constructive comments on an earlier version of the paper, which helped enhance its quality.
} 


\title{
'BETTER A WITTY FOOL THAN A FOOLISH WIT' (MEJOR UN TONTO INGENIOSO QUE NO UN INGENIO TONTO): SOBRE LOS JUEGOS DE PALABRAS EN LOS PEDANTES Y BUFONES DE SHAKESPEARE
}

\begin{abstract}
RESUMEN. Uno de los distintivos de la singularidad del estilo de Shakespeare es sin duda su hábil uso de los juegos de palabras. Además de estar hábilmente entrelazados en la textura dramática de sus obras, su gran fuerza también descansa en el hecho de que están cuidadosamente confeccionadas para satisfacer tanto las necesidades dramáticas como conversacionales de cada personaje. Este artículo pretende poner el foco en dos estilos diferentes de juegos de palabras de los personajes dramáticos de Shakespeare tal y como los desarrollan los pedantes (representados aqui por Holofernes en Trabajos de amor perdidos) y los bufones (ejemplificados por Feste en La Duodécima noche o Noche de Reyes). Al examinar las peculiaridades de los dobles sentidos en términos de la cantidad, la semántica, la dinámica conversacional y la configuración de los participantes, este estudio demuestra que los dos personajes representan los polos opuestos del arte del doble sentido. Mientras que el bufón se muestra como un virtuoso creador de juegos de palabras proporcionando conversaciones ingeniosas cada vez que se da la ocasión, los juegos de palabras del pedante son excesivamente sofisticados y eruditos y así resultan altamente incomprensibles y de efecto plano.
\end{abstract}

Palabras clave: Lenguaje con doble sentido, juegos de palabras, inglés de la época de Isabel, comedias de Shakespeare, bufón, pedante.

Received 29 August 2012

Revised version accepted 30 September 2013

\section{PRELIMINARIES}

\subsection{A NOTE ON A PUN}

The phenomenon under investigation presents a lot of closely interlaced definitional, terminological and typological difficulties. In the growing body of critical literature on the subject it is discussed under a broad array of, more or less capacious, names. Some of these include 'play on words', 'wordplay', 'word games', 'pun', 'play with words', 'language game', 'play of language' in English, 'Wortspiel', 'Sprachspiel', 'Spiel mit der Sprache' in German, 'jeux de mots', 'jeux avec les mots', 'jeux sur les mots', 'jeux de langage' in French or 'igra słow', 'jazykowaja igra' in Russian (Szczerbowski 1998: 34). By and large, the extent of terminological rigour depends on the overarching research perspective adopted in individual studies as well as their principal objectives, and so, for instance, 
'BETTER A WITTY FOOL THAN A FOOLISH WIT': ON PUNNING STYLES OF SHAKESPEARE'S...

literary scholars tend to favour a more relaxed approach to the nomenclature in the field than linguistically-oriented academics.

Another problem area appears to be taxonomy which fuels a major controversy over the legitimacy and feasibility of categorising language-based humour into well-defined types. A firm belief that it lends itself readily to scrupulous pigeon-holing, where the boundaries of individual classes are delineated without unwelcome overlap, can be found in Wurth (1895) and, much later, in Heibert (1993). Other typological attempts worth mentioning include Freidhof's (1984), where a binary (either/or) approach to the classification of puns is likened to the description of phonemes in terms of clusters of distinctive features, and Heller's (1974), where altogether eleven criteria are deemed indispensable for a reliable taxonomic account of the phenomenon. In contrast, a deep scepticism about the value of a painstaking categorisation of puns is voiced, among others, by Esar (1954), Mahood (1957), Redfern (1984) and Culler (1988), who consider drawing sharp, often oversubtle, distinctions between individual classes to be counterproductive.

Refocusing the attention back onto terminology, in the present study the above mentioned English labels are regarded as synonymous and used interchangeably, yet a slight numerical preference is given to the name 'pun' which, comparatively speaking, appears to be defined more rigidly in the relevant academic publications. Following Delabastita, the phenomenon is assumed to involve a "(near-)simultaneous confrontation of at least two linguistic structures with more or less dissimilar meanings (signifieds) and more or less similar forms (signifiers)" (1993: 57). Formally, then, the linguistic trigger mechanisms for a pun include those of homonymy, homophony, homography and paronymy, while the semantic criterion for its emergence is met by an appreciable distance between the meaning components at play. ${ }^{2}$

\subsection{ELIZABETHAN ENGLISH AS A PUN-FRIENDLY LINGUISTIC ENVIRONMENT}

Shakespeare's predilection for experimenting with the interplay of forms and meanings in words makes him a man of his times. Indeed, in the Elizabethan era wordplay enjoyed such a high status that "it was almost de rigueur in the conversation of English courtly society, in the jest-books, ballads, and broadsides

\footnotetext{
2 a. See also section 1.2. for a brief comment on the impossibility of generating homographic puns in the disorderly $16^{\text {th }}$-century orthographic system.

b. Numerous synchronic and diachronic difficulties inherent in the description of a highly gradable nature of semantic contrast in the homonymic variety of puns are discussed at length in Delabastita (1993) and Hausmann (1974).
} 
of popular literature, and even, according to Addison, in much more serious language" (Ellis 1973: 12). ${ }^{3}$

Presumably, besides echoing the spirit of the day, the vogue was, at least to some extent, a corollary of massive changes in $16^{\text {th }}$-century English, which unlocked its considerable punning potential. The developments which remodelled the existing linguistic system occurred on two distinct planes of language, viz. lexis and pronunciation. The lexical innovations, which affected quantitatively the homonymic type of puns alone, were concerned with a largescale importation of foreign words from a number of languages (modern and ancient) via educational channels or, otherwise, through close trade and colonial contacts. This wide-ranging borrowing process, which was in fact a sequel of an analogous one operating already in the Middle English period (though essentially confined to Romance loan words), immediately met with a strong disfavour among language purists, who would rather have seen English cleansed of a foreign element, and was to spark off heated debates long after. Irrespective of the response these lexical changes elicited, they undoubtedly led to a rapid emergence of synonyms. This, in turn, "brought with it an unceasing differentiation in usage as well as in meaning and connotation, which was eminently favourable to punning and other forms of conscious or unconscious verbal ambiguity [...]" (Kökeritz 1953: 54). ${ }^{4}$

On the phonological plane, the changes which proved to be most conducive to a vast increase in puns, yielding a true wealth of homophonic forms, were predominantly pre-Elizabethan and took the form of what is routinely referred to as the Great Vowel Shift (GVS), initiated in all likelihood in the latter half of the $13^{\text {th }}$ century and completed two hundred years later. In the wake of these revolutionary changes, which upset the entire Middle English system of long vocalic and diphthongal phonemes, the English language built up an impressive collection of new homophonic forms, and while some of them were, as a result of further sound evolution, irretrievably lost shortly after, a number of subsequent systemic transformations came about, which were soon to successfully redress the quantitative balance (Kökeritz 1953: 54; Kohl 1966: 68).5

\footnotetext{
3 Aside from Shakespeare, the leading punsters on the $16^{\text {th }}$-century literary arena were Lyly, Spenser, Green, Lodge, Nash and Kyd (cf. Wurth 1895 and Kohl 1966).

4 Cf. also Kohl: "[D]ie Latinisierung der englischen Sprache im 16. Jahrhundert und das Eindringen von französischen und gemeinromanischen Wörtern [...] [begründeten] den enormen Wortreichtum, der sich vor allem in den Synonymen zeigt [...] Dadurch eröffneten sich vorher nicht gekannte stilistische Möglichkeiten der sprachlichen Differenzierung und Nuancierung" (1966: 69).

5 It should not go unrecognised at this point that the potential of Elizabethan English for homophonic punning might have been in addition appreciably boosted by a strong presence of phonetic doublets
} 
'BETTER A WITTY FOOL THAN A FOOLISH WIT': ON PUNNING STYLES OF SHAKESPEARE'S...

Interestingly enough, the $16^{\text {th }}$-century English orthographic system emerges as "full of irrationalities and inconsistencies" (Schlauch 1959: 81), which can be chalked up to a number of factors, including, most notably, the sloppiness of language users, the introduction of stylish, pseudo-learned spellings modelled on Greek, Latin and French (turning, for instance, the native rime into rhyme, saume into psalm, etc.) and the erroneous extension of Germanic-like spelling to Romance loan-words (yielding delight in lieu of delite or spight in preference to spite) (Schlauch 1959: 81-82). The unwieldy disorderliness of the system stimulated the leading intellects of the day (chiefly John Hart, William Bullokar and Richard Mulcaster) to make a valiant and long overdue effort to conventionalise English spelling (Schlauch 1959: 82-83). Sadly, none of these attempts proved successful in the long run, all but marginally improving on the original system. It is, therefore, reasonably safe to assume that in Shakespeare's times "people still spelled very much as they pleased" (Kökeritz 1953: 20). This, quite expectedly, had a direct bearing on punning practices in that it altogether dismissed the possibility of the emergence of homographic forms, capable of surfacing only in a perfectly codified spelling system (cf. Hill 1988: 67). As regards Shakespeare's language specifically, Kökeritz observes that "no Shakespearean pun was ever based upon the spelling of a word; either meaning or pronunciation is involved, but never orthography" (1953: 87).

\section{THE RESEARCH OBJECTIVES, METHOD AND DATA}

The study sets out to juxtapose two individual punning idioms, as evolved by the Shakespearean pedants and jesters ${ }^{6}$ (represented respectively by Holofernes in Love's Labour's Lost (henceforth LLL) and Feste in Twelfth Night (hereafter $T N$ )), by virtue of examining the features that make up their

(e.g. a diagraph ea standing, in an alternating fashion, both for [i:], as evidenced by the rhyme beseech : teach, and [e:] or [e]) as well as by the practice of skilful phonetic manipulation, where regular pronunciations of the day were supplanted with substandard varieties of dialectal or vulgar parentage (Kökeritz 1953: 21, 65-66; Delabastita 1993: 85). Similarly, Schlauch argues that in $16^{\text {th }}$ century English "there were still a number of possibilities of choice among equally 'correct' forms, because conservative and advanced pronunciations could be heard side by side, as well as competing dialect forms and even vulgarisms which were beginning to be accepted" (1959: 85).

6 In the Elizabethan times a licensed joker at courts or in large households was also labelled 'clown' and 'fool'. For the sake of terminological clarity, however, in the present paper the term 'clown', which was more commonly used with reference to 'an unsophisticated countryman or rustic', is applied solely in the latter sense of the word to country bumpkins, whereas 'fool', risky due to a potential confusion between its two meanings (i.e. 'a principal comedian' and 'a simpleton'), is essentially avoided, unless necessary or unequivocal. 
idiosyncratic character. ${ }^{7}$ One of the central methodological tenets is that the characters of Shakespeare's comedies, as incumbents of professional and private roles, function as social types rather than individuals, and as such come equipped with a common set of characteristics (also linguistic) in different plays. Accordingly, generalising from the behaviour of a single personage to that of an entire group of characters representing a single stock figure, as sometimes done in the paper, is believed to be in line with the rules of methodological rigour. ${ }^{8}$ Another fundamental assumption underpinning the study is that, in order to neatly capture the dynamics of punning as defined by its contextual embeddedness, it is not so much isolated instances of puns as more sizeable chunks of wordplay-dependent interactions that should come under especially careful scrutiny, which is the practice followed in the study.

One significant feature of a dramatic text that should not pass unnoticed when discussing the employed research method is that it is a written-to-bespoken mode of communication, inexorably lacking the spontaneity of natural speech. Yet, in Herman's opinion, “[t]he principles, norms and conventions of use which underlie spontaneous communication in everyday life are precisely those which are exploited and manipulated by dramatists in their constructions of speech types and forms in plays" (1995: 6). Following this belief, the examined puns, despite being a product of Shakespeare's deliberate effort and informed choices, are treated as elements of naturally occurring communication rather than as any artificial formations.

Last but not least, the process of retrieving the data and interpreting their complex semantic content was not entirely free from difficulties arising from the fact that some of the meanings which were the building blocks of Shakespeare's play of language are now obsolete, and others tightly interlaced and hard to disentangle. Forcing the way through this labyrinthine network of, often outdated, meanings was significantly aided by explanations found in the dictionaries and lexicons of Shakespeare's language in general and wordplay in particular (chiefly Onions 1919 and West 1998), as well as in insightful editorial and critical comments on his plays.

\footnotetext{
7 Since the present study is part of a larger research project, where a wider sample of punsters cast in a broader range of social roles was collected and analysed, occasional references to their punning practices are made for comparison throughout the paper.

8 At the same time due care is taken to avoid similar generalisations to real-life figures, which might lead to an unwelcome distortion of the historical reality (cf. also Calvo (1991: 5) who, discussing Shakespeare's fools specifically, cautions against drawing a direct parallel between these characters as fictitious figures and real domestic jesters).
} 
'BETTER A WITTY FOOL THAN A FOOLISH WIT': ON PUNNING STYLES OF SHAKESPEARE'S...

\section{THE STUDY}

\subsection{AN ENQUIRY INTO PUNNING PRACTICES OF THE SHAKESPEAREAN PEDANT: THE CASE OF HOLOFERNES IN LLL}

Given Holofernes' frequent stage appearance, the total number of his puns, equalling 25 instances, can be described as relatively small or mean, which surely does not make him the leading representative of the category of heavy punsters. ${ }^{9}$ At the same time, these few examples suffice to notice that the pedant's wordplay constitutes a distinctive variety and, as such, deserves a separate treatment.

In order to fully understand its uniqueness, at least a fleeting glance at the schoolmaster's approach to and use of language seems indispensable. Without a shadow of doubt Holofernes' speech style is the most stilted and ornate in the entire play, and it is an extremely daunting task to force one's way through it. Next to stiff syntax, the gravest difficulties are presented by sophisticated lexis, as seen in a heavy (yet often erroneous) use of complex Latinate and Latin vocabulary as well as of numerous rhetorical devices (principally synonymy, metaphor, alliteration and assonance). Overloading language in this way, regarded by the Elizabethans as a hallmark of brilliancy, is an inevitable consequence of the $16^{\text {th }}$-century educational training policy biased towards teaching rhetoric, the cornerstone of erudition, apparently valued more than wisdom. Equally intriguing is Holofernes' orthodox approach to the phonological aspect of language, where alternative, modernised pronunciations, though prevalent in spontaneous speech, are strongly disfavoured and traditional ones considered, accordingly, the only acceptable choices. The following is believed to be a fairly representative sample of the pedant's verbal excesses:

(1) Holofernes: "Most barbarous intimation! Yet a kind of insinuation, as it were in via, in way of explication; facere, as it were replication, or, rather, ostentare, to show, as it were, his inclination, - after his undressed, unpolished, uneducated, unpruned, untrained, or rather unlettered, or ratherest, unconfirmed fashion - to insert again my haud credo for a deer. (LLL, IV.II.13-20)

\footnotetext{
9 The pun count in the paper is kept on the basis of the number of tokens rather than types of puns produced by individual characters (however, cf. also Adamczyk (2010: 186-187) for a brief synopsis of potential hazards of representing Shakespeare's play on words quantitatively).
} 
All this builds up a bleak picture of Holofernes' language which turns out to be not only syntactically and lexically intricate but, most importantly, permanently fixed, blocking any reform of its internal structure. As might be predicted, it is at the same time deeply hostile to any spontaneous linguistic phenomena such as wordplay, which rests on twisted meanings and, not infrequently, manipulated pronunciations, i.e. chaos rather than order. Given Holofernes' attitude towards language, tracing as many as 25 occurrences of puns in his speech may seem surprising on the surface of it. It remains to be positively evidenced, however, that the schoolmaster's playing with words is essentially not at odds with his vision of the use of language, though, in a way, it constitutes the exception to the rule. It seems that the simplest explanation for this curious paradox lies in Holofernes' careful choice of punning strategies as well as contextual settings for his word games.

The most spectacular punning effected by the tutor appears to be the following monologue - "an extemporal epitaph on the death of the deer" (IV.II.49-50) killed by the Princess:

(2) Holofernes: I will something affect the letter; for it argues

facility.

The preyful princess pierc'd and PRICK'D a pretty pleasing PRICKET; Some say a SORE; but not a SORE, till now made SORE with shooting. The dogs did YELL; put 'ELL to SORE, then SOREL jumps from thicket; Or PRICKET SORE, or else SORE'LL the people fall a-hooting. If SORE be SORE, then 'ELL to SORE makes fifty SORES - O - SOREL! Of one SORE I an hundred make, by adding but one more $L$.

Nathaniel: A rare TALENT!

Dull: If a TALENT be a CLAW, look how he CLAWS him with a TALENT. (LLL, IV.II.55-65)

[The following meanings lay the groundwork for the above punning interaction: PRICK'D/PRICKET $($ s1 (sense 1$)=$ stabbed, wounded $/$ s2 $($ sense 2$)=$ a two-year-old red deer), $S O R E$ (s1 = a four-year-old deer; s2 = irritation, wound, ulcer; irritated, wounded), $Y E L L / E L L[L](\mathrm{s} 1=\mathrm{cry}$, howl / s2 = (spoken form of $)$ the letter of the alphabet), SORE+ELL [L]/SOREL ( $\mathrm{s} 1=\mathrm{a}$ deer of four years + (spoken form of) the letter of the alphabet $/ \mathrm{s} 2=$ a male deer in its third year; $s 3=$ sorrel, a perennial herb with acidic-tasting leaves used in cookery (sorrel soup/stew is commonly found in recipe collections from the EMod period) and for medicinal purposes (e.g. to alleviate the pain caused by an insect or plant sting); $s 4=$ (also spelt 'sorrel') a popular name for a specific type of character in pastoral literature of the late $16^{\text {th }}$ century), $E L L[L] / L$ ( $\mathrm{s} 1=$ (spoken form of) the letter of the alphabet $/ \mathrm{s} 2=$ the Roman numeral for 50), TALENT ( $1=$ a gift, flair; s2 = a talon $($ common old form $)), C L A W / C L A W S\left(\mathrm{~s} 1=\right.$ a talent $/ \mathrm{s} 2=$ flatters $\left(3^{\text {rd }}\right.$ pers. sing. $\left.\left.)\right) .{ }^{10}\right]$

10 The adopted method of presenting the interplay of meanings follows Delabastita's (1993) convention. 
'BETTER A WITTY FOOL THAN A FOOLISH WIT': ON PUNNING STYLES OF SHAKESPEARE'S...

The reconciliation of Holofernes' radical approach to language with a pretty liberal use of puns in this passage is possible upon recognising the fact that the verbal play practiced by the pedant is as ornamental and impenetrable to his recipients (i.e. his devotee, Nathaniel -a hedge-priest and Dull- a constable) as his language in general. With this end in view, the tutor not only embellishes his puns with alliterative style but also makes the proper understanding of them dependent on, at least a rudimentary, knowledge of Latin (namely, the ability to recognise the letter a $L$ as the Roman numeral for fifty) as well as of an intricate system of names given at that time to various kinds of deer, depending on their maturity (see the explanatory note below example 2). Despite all Holofernes' efforts, his puns turn out to be forced and their overall effect fairly insipid. Pedantically pre-arranged, they do not compare to impromptu punning exchanges of the Shakespearean pages, and it seems that even the punning commentary on Holofernes' verbal show made by Dull (after Costard, surely the least brainy figure in the play) proves more riveting. This qualitative judgement on the schoolmaster's wordplay tallies nicely with Wurth's (1895) critical appraisal of the so-called 'Cyklonenspiele' (i.e. semantically concatenated puns piled on top of one another), of which the above puns are a prime example. ${ }^{11}$ Somewhat counter-intuitively, but apparently rightly, Wurth finds this type of puns relatively weak, referring to them as "weniger gute Spiele" (1895: 146).

Even though Holofernes succeeds in making his language game unique, he does not seem to feel comfortable about the very fact of indulging in the lowest kind of verbal wit, for which he, accordingly, needs some rational justification. The following is his own desperate attempt to provide one:

(3) Holofernes: This is a gift that I have, simple, simple; a foolish extravagant spirit, full of forms, figures, shapes, objects, ideas, apprehensions, motions, revolutions: these are begot in the ventricle of memory, nourished in the womb of pia mater, and delivered upon the mellowing of occasion. But the gift is good in those in whom it is acute, and I am thankful for it. (LLL, IV.II.66-72; italics on the last sentence added)

\footnotetext{
11 Under Wurth's definition, "[b]ei diesen wird mittelst einer Reihe von Wortspielen um einen Begriff im Kreise herumgegangen" (1895: 147). In fact, 'Cyklonenspiele' belong to the sub-category of 'Gruppenspiele' which "lassen sich meist in die einfachen Spiele zerlegen [...] sie sollen wenigstens durch den Sinn so innig verbunden sein, dass eine Trennung ohne Schaden für das Ganze nicht stattfinden kann. Als äußeres Bindemittel der Einzelspiele wird zuweilen die Alliteration etc. angewendet" (1895: 146).
} 
Another exception to Holofernes' normally non-punning use of language is the following passage:

(4) Jaquenetta: God give you good morrow, master PERSON.

Holofernes: Master PERSON, quasi PIERCE-ONE. An if one should

be PIERCED, which is the one?

Costard: Marry, master schoolmaster, he that is likest to a HOGSHEAD.

Holofernes: Of PIERCING a HOGSHEAD! A good lustre of conceit in a turf of earth; fire enough for a flint, pearl enough for a swine: 'tis pretty; it is well. (LLL, IV.II.81-88)

[The above punning exchange pivots on the following meaning components: PERSON/PIERCE-ONE (s1 = (obsolete spelling of parson) a clergyman, preacher $/ \mathrm{s} 2=$ (possibly spelt 'pers-on' by the Elizabethans) to sting, hurt, offend someone), PIERCE/PIERCED/PIERCING (s1 = (also spelt 'Piers') a traditional literary name in English (cf. Piers in Piers Plowman); in pastoral literature, for instance, the name normally given to one particular type of character / s2 = stung, hurt, offended / s3 = part of the phrase piercing a hogshead, i.e. 'getting drunk'), HOGSHEAD (s1 = a thick-witted person; s2 = part of the phrase to pierce a hogshead, i.e. 'to get drunk').]

With a single exception, the above is the only example of the schoolmaster's interactional punning. ${ }^{12}$ The feature which distinguishes it from his previous attempt at a playful use of language, and its strength at the same time, is its spontaneity and unpretentiousness. This marked shift in punning style, resulting mostly from the decision to engage in a dialogical play on words, is hardly fortuitous and seems to be closely related to the specificity of the participant configuration, Holofernes' recipients being his social inferiors, i.e. Jaquenetta (a country wench) and Costard (a country bumpkin). The very fact of stooping to punning with such low-ranking characters is apparently an attempt to socialise with them. Accordingly, making his puns more readily accessible and down-toearth (as seen especially in the use of the $16^{\text {th }}$-and $17^{\text {th }}-$ century idiomatic slang expression to pierce a hogshead meaning 'to get drunk') can be regarded as the pedant's strategy towards tailoring his language to intellectual abilities of his

12 The following is the exceptional case:

(5) Nathaniel: Sir, you have done this in the fear of God, very

religiously; and, as a certain FATHER saith, -

Holofernes: Sir, tell not me of the FATHER;

I do fear COLOURABLE COLOURS. [...] (LLL, IV.II.146-149)

[The semantic composition of the above puns is the following: FATHER (s1 = a priest, parson (used as a title); $\mathrm{s} 2$ = a begetter, male parent), COLOURABLE/COLOURS (s1 = plausible, specious $/ \mathrm{s} 2=$ pretexts, pretences, the appearance of right; $\mathrm{s} 3=$ (as in the stock phrase fear no colours 'fear no enemy') military (enemy's) ensigns, standards).] 
'BETTER A WITTY FOOL THAN A FOOLISH WIT': ON PUNNING STYLES OF SHAKESPEARE'S...

addressees, which is both generous and strategic (i.e. intended to make communication between them effective). The sole reason why a similar strategy was not pursued in the passage quoted in example 2 is, in all likelihood, the fact that the entire verbal show was meant to impress Nathaniel, Dull being, from Holofernes' point of view, a virtually redundant recipient. Finally, an alternative explanation for the schoolmaster's more carefree punning in interactions with his social inferiors (which, paradoxically, produces better results than his stilted wordplay) may emerge from the fact that it is only in the company of such participants that he can momentarily stop parading his sophisticated language.

Exceptionally, the final example presents Holofernes as an outpunned party rather than a punster, providing tangible evidence that he miserably fails to cope with the type of punning which develops into a battle of wits. The pedant is here cast in the role of actor playing Judas in the Pageant of the Nine Worthies:

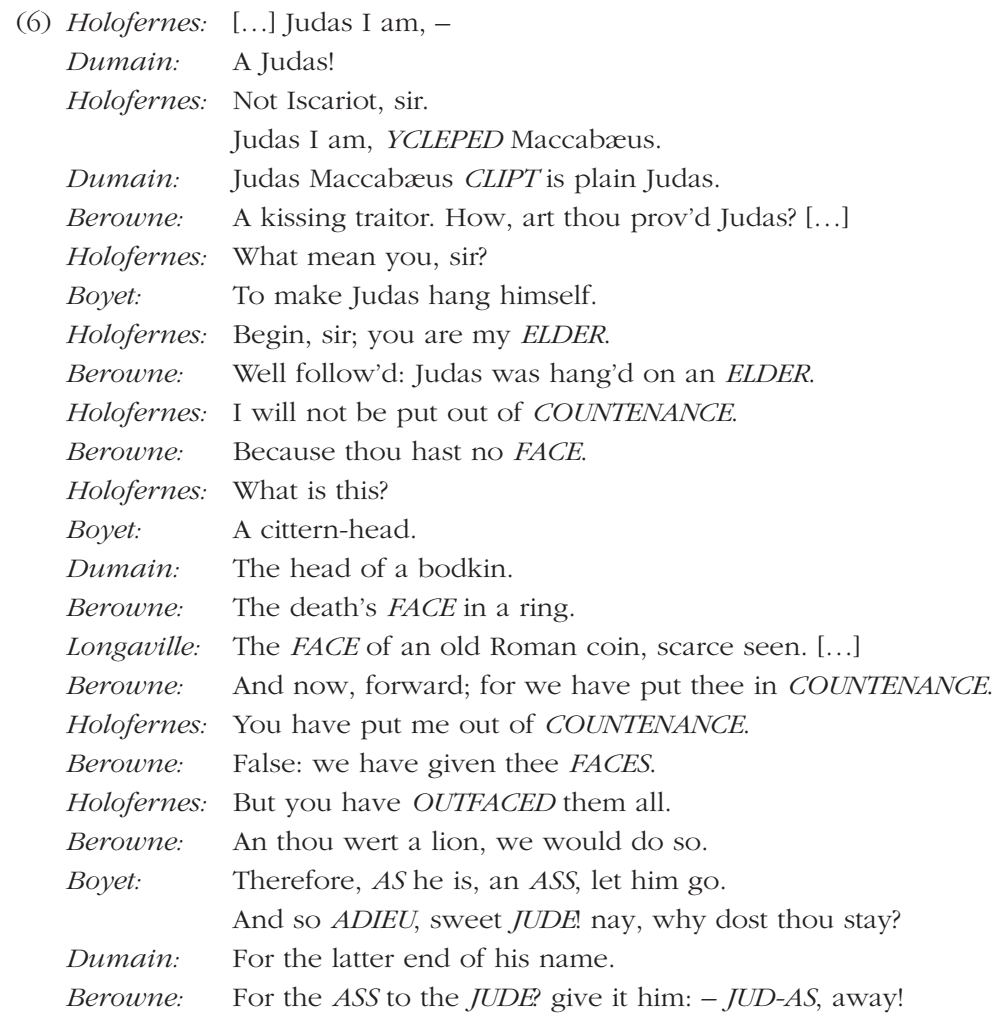


Holofernes: This is not generous, not gentle, not humble. (LLL, V.II.588-593; 596-606; 612-621)

[The meanings brought to the fore in the above interaction include the following: YCLEPED/CLIPT (s1 = called, named $/ \mathrm{s} 2=$ sheared, abbreviated, curtailed; $\mathrm{s} 3=$ embraced, surrounded), $E L D E R$ (s1 = older; s2 = a small tree with pithy stems; (in the Christian tradition) the type of tree from which Judas hanged himself), COUNTENANCE (s1 = as in the phrase out of countenance 'disconcerted, distracted, unsettled'; $s 2=$ a person's face or facial expression), FACE (s1 = physiognomy; $\mathrm{s} 2=$ the front side of coins, flasks, rings, brooches, etc., presented to the view), FACES/OUTFACED (s1 = the plural of $\mathrm{s} 2$ in the previous entry / s2 = intimidated, browbeaten, put out of countenance), AS/ASS (s1 = since, because $/ \mathrm{s} 2=\mathrm{a}$ foolish, stupid person), $A D I E U /(A J E W) / / J U D E(\mathrm{~s} 1=\mathrm{a}$ farewell $/ \mathrm{s} 2=\mathrm{a}$ representative of the Jewish nation $/ / \mathrm{s} 3=$ an Apostle (also known as Judas)), $J U D E+A S S / J U D-A S(\mathrm{~s} 1=\mathrm{s} 3$ in the previous entry + a foolish, stupid person $/ \mathrm{s} 2=$ an Apostle; someone who betrays a comrade).]

As in any punning duel, puns made here by the victimising parties, i.e. lords, are all classic examples of overt Face Threatening Acts (FTAs) intended against their discourse partner, i.e. Holofernes. As evident from the final sentence, which is the schoolmaster's (indirect) admission to having been outmanoeuvred, they turn out hugely successful. To be sure, the insurmountable difficulty in repelling the lords' attack is caused by his failure to use their own weapon against them. Outwitting his rivals, however, proves impossible, as it requires agile mind and spontaneity which Holofernes, who values only sophisticated foreign vocabulary and erudition, apparently lacks.

\subsection{AN ENQUIRY INTO PUNNING PRACTICES OF THE SHAKESPEAREAN JESTER: THE CASE OF FESTE INTN}

While, terminologically, Feste's role in the play may be easily confused with Costard's, for instance, or Lance's in TGV (The Two Gentlemen Of Verona), all these characters being routinely referred to as 'clowns' or 'fools' (see also footnote 5), the evidence of puns shows clearly that he shares little common ground with these figures. In fact, the most fitting description of his professional duty as jester is provided by himself in one of his punning interactions with Viola, disguised as a male:

(7) Viola: Art not thou the Lady Olivia's FOOL?

Feste: No, indeed, sir. The Lady Olivia has no folly. She will keep no FOOL, sir, till she be married, and FOOLS are as like husbands as pilchards are to herrings - the husband's the bigger. I am indeed not her FOOL but her corrupter of words. (TN, III.I.26-30; italics on the non-capitalised words added) 
'BETTER A WITTY FOOL THAN A FOOLISH WIT': ON PUNNING STYLES OF SHAKESPEARE'S...

[The above pun on FOOL rests on the following interplay of meanings: $\mathrm{s} 1=\mathrm{a}$ jester (especially one retained in a great household); $s 2$ = a simpleton, ass, dullard.]

One may gain the impression that Feste, with his 65 puns, fits into the category of fairly prolific punsters. However, given that it is the province of jesters to deliberately twist meanings just for the fun of it, Feste could be expected to have a big lead over the rest of the punning figures, which is not the case. The explanation for this lies, most probably, in the fact that in $T N$, a late comedy, Shakespeare is no longer obsessed with the idea of punning whenever opportunity offers. Accordingly, the jester is not only cast in the role of punster, the "corrupter of words" (TN, III.I.30), as he chooses to label himself (cf. example 7 above), but he also frequently practices the wit of ideas.

Unlike other punsters, Feste does not select suitable partners to pun with, but he practices verbal play with all his interlocutors (i.e., in order of entry, Maria, Olivia, Sir Andrew, Viola, Sebastian, Sir Toby, Malvolio, Fabian and Orsino), irrespective of their social standing. Accordingly, it comes as little surprise that he does not hesitate to pun even with the highest-ranking figure in the play, Duke Orsino, as illustrated below:

(8) Orsino: Thou shalt not be the worse for me; there's gold.

Feste: But that it would be DOUBLE-DEALING, sir, I would you could make it another.

Orsino: O you give me ill counsel.

Feste: Put your GRACE in your pocket, sir, for this once, and let your flesh and blood obey it.

Orsino: Well, I will be so much a sinner to be a DOUBLE-DEALER; there's another.

Feste: Primo, secundo, tertio is a good play, and the old saying is 'The third pays for all'; the TRIPLEX, sir, is a good TRIPPING measure; or the bells of St Bennet, sir, may put you in mind - one, two, three.

Orsino: You can FOOL no more money out of me at this THROW. If you will let your lady know I am here to speak with her, and bring her along with you, it may awake my bounty further. (TN, V.I.21-34)

[The meanings toyed with above include the following: DOUBLE-DEALING (s1 = duplicity, trickery; s2 = double-giving, giving twice over), GRACE (s1 = a favour; s2 = a form of address for a duke/duchess), TRIPLEX/TRIPPING (s1 = triple time in music / s2 = dancing or walking with quick light steps), $F O O L$ (s1 = to trick, make a fool of someone; $\mathrm{s} 2$ = a jester (especially one retained in a great household)), THROW (s1 = a venture, occasion; $s 2=$ a cast of the dice).]

To be sure, the most conspicuous peculiarity about Feste's wordplay, and more specifically its semantic composition, is his frequent playing on the meaning 'fool', which takes on a self-referential character as a commentary on 
the profession of jester. The exchanges quoted below, where he interacts with Olivia (his lady) and Malvolio (her steward), are all intended as an illustration of this idiosyncrasy (see also example 7 above):
(9a) Malvolio:
Ay, good FOOL.
Feste:
Alas, sir, how fell you besides your five wits?
Malvolio: FOOL, there was never man so notoriously abused. I am as well in my wits, FOOL, as thou art.
Feste: $\quad$ But as well? Then you are mad indeed, if you be no better in your wits than a FOOL. (TN, IV.II.71-76)
(9b) Olivia:
Feste:
What's a drunken man like, FOOL?
(9c) Feste:
Olivia:
Feste:
Olivia: Like a drowned man, a FOOL, and a madman: one draught above heat makes him a FOOL, the second mads him, and a third drowns him. (TN, I.V.107-110)
Feste:

$$
\text { [...] God bless thee, lady. }
$$$$
\text { Take the FOOL away. }
$$
Feste: Do you not hear, fellows? Take away the lady.

Feste:
Go to, y'are a DRY FOOL: I'll no more of you; besides, you grow dishonest.
Two faults, Madonna, that drink and good counsel will AMEND: for give the DRY FOOL drink, then is the FOOL not DRY; bid the dishonest man MEND himself; if he MEND, he is no longer dishonest; if he cannot, let the botcher MEND him. Anything that's MENDED is but patched: virtue that transgresses is but patched with sin, and $\sin$ that $A M E N D S$ is but patched with virtue. [...] (TN, I.V.30-40)

\footnotetext{
[The meanings at play in examples 9a, 9b and 9c can be elucidated as follows: FOOL (s1 = a jester (especially one retained in a great household); $\mathrm{s} 2$ = a simpleton, ass, dullard), DRY ( $\mathrm{s} 1$ = (of a jest) dull, flat or caustic; s2 = thirsty), (A)MEND (mend being an aphetic form of amend) (s1 = to repair, fix; s2 = to improve in moral standards, reform).]
}

While it is little surprising that the jester unlocks the assaultive potential of the word fool in exchanges with Malvolio (example 9a), his bitter foe, and with Olivia (example 9b), where in fact a third party, Sir Toby (a kinsman of Olivia's), is being fooled, his direct attack on the lady in the last example is somewhat astonishing. Apparently, punning as a professional duty, primarily intended to entertain (if only on the surface), does not have to be finely adjusted to the type of interlocutor. At the same time, even though the jester's assaults are first and foremost designed to arouse laughter, his wordplay rarely seems all innocent and devoid of some additional function in the play. It is probably not coincidental, though surely ironic, that each of Feste's addressees is at least once called 'a fool' by the leading representative of the category of fools himself. This seems to 
'BETTER A WITTY FOOL THAN A FOOLISH WIT': ON PUNNING STYLES OF SHAKESPEARE'S...

point to the conclusion that the jester's wordplay has a reflexive character in that it provides a foil for human folly, even though no particular kind thereof is being ridiculed. ${ }^{13}$ Accordingly, there may be at least a modicum of justification for his conviction that he "wear[s] not motley in the brain" (I.V.46) and some logic in the following philosophy which he adopts:

(10) Feste: Wit, and't be thy will, put me into good fooling! Those wits that think they have thee do very oft prove fools, and I that am sure I lack thee may pass for a wise man. For what says Quinapalus? 'Better a witty fool than a foolish wit' [...]. (TN, I.V.27-30)

It needs to be highlighted finally that Feste's wordplay never assumes the form of spectacular 'ping-pong punning'. ${ }^{14}$ This can be attributed to the fact that none of his interlocutors seem capable of keeping pace with him, save for Maria, a waitingwoman, who for some reason misses the opportunity to do that, but is still the only character to twist the jester's meanings at all, which is done once in the whole play:

(11) Feste: [...] I am resolved on two POINTS -

Maria: That if one break, the other will hold, or if both break, your gaskins faill. (TN, I.V.19-21)

[The above pun on POINTS pivots around the following senses: $\mathrm{s} 1=$ matters, issues, topics; $\mathrm{s} 2$ = tagged laces used for attaching breeches to a doublet.]

An attempt to respond to Feste's wordplay in a punning mode is also made by Viola but, unlike in Maria's case, it proves clumsy, which is made crystalclear by the jester himself:

(12) Viola: Save thee, friend, and thy music! Dost thou LIVE BY thy tabor?

Feste: No, sir, I LIVE BY the church.

Viola: Art thou a churchman?

Feste: No such matter, sir. I do LIVE BY the church; for I do live at my house, and my house doth STAND BY the church.

Viola: So thou mayst say the king LIES BY a beggar, if a beggar dwell near him; or the church STANDS BY thy tabor if thy tabor STAND BY the church.

\footnotetext{
13 Along similar lines (but somewhat more socio-politically), Calvo observes that in their professional roles as jesters "Shakespeare's fools become a subversive social institution: they defy the established order by pretending to serve it. They show how authority can be challenged with wit and humour under the appearance of providing entertainment for the very same authority that is being challenged" (1991: 6).

14 This illustrative term is borrowed from Chiaro, where it is said to be "used to describe what happens when the participants of a conversation begin punning on every possible item in each other's speech which may contain the slightest ambiguity" (1992: 114).
} 
Feste: You have said, sir. To see this age! A sentence is but a cheveril glove to a good wit - how quickly the wrong side may be turned outward!

Viola: Nay, that's certain: they that dally nicely with words may quickly make them WANTON.

Feste: I would therefore my sister had had no name, sir.

Viola: Why, man?

Feste: Why, sir, her name's a word, and to dally with that word might make my sister WANTON; but, indeed, words are very rascals, since bonds disgraced them. (TN, III.I.1-18)

[The following meanings are brought into play in the above puns: LIVE BY (s1 = to make a living by; $s 2$ = to dwell nearby, beside), LIES BY (s1 = s2 in the previous entry ( $3^{\text {rd }}$ pers. sing.); $\mathrm{s} 2=$ lies with, i.e. has sexual intercourse with), STAND BY (s1 = to be located nearby; s2 = to be maintained by), WANTON/(WANT ONE) (s1 = wayward, unrestrained, capricious; s2 = licentious, promiscuous, lecherous $/ \mathrm{s} 3=$ to desire somebody/something).]

In all likelihood, the role of an active punning partner of jester would be best played by page, given that a close parallel (quantitative and qualitative alike) can be drawn between the types of wordplay practiced by the two categories of punsters. In the plot line of $T N$, however, no room is left for this stock figure.

\section{CONCLUSIONS}

Bringing the discussion to an end, the most relevant facts about Holofernes' idiosyncratic punning style can be reiterated in summary form as follows:

a. Essentially, the pedant's orthodox approach to language leaves little room for puns, which are regarded as phenomena upsetting the desired stability and predictability therein.

b. The only brand of verbal humour acceptable to the schoolmaster appears to be that which involves scrupulously pre-arranged, sophisticated and inaccessible puns; these, however, turn out to produce rather a vapid effect.

c. While more common-or-garden, interactional punning appears sporadically in Holofernes' exchanges with socially low-ranking characters, it is normally looked down upon by the pedant as a simplistic verbal exercise. The fact which he fails to realise is that lively punning exchanges are, at the same time, beyond his intellectual capabilities, requiring open mind rather than flowery language.

d. Holofernes' play with words, rare as it is, seems to offer firm evidence that he is a stock example of the Shakespearean pedant, for whom the 
'BETTER A WITTY FOOL THAN A FOOLISH WIT': ON PUNNING STYLES OF SHAKESPEARE'S...

knowledge (often superficial) of sophisticated words appears to be primary to a clever use of them.

e. More generally, a close look at the schoolmaster's punning style makes it possible to hypothesise that the cumulative use of puns, as seen in example 2 above, produces more spectacular results in interactive, impromptu speech than in monologues.

Even though punning on words is not the only province of jester, he is beyond a shadow of doubt one of the key figures in the humorous discourse of Shakespeare's comedies. The most essential facets of his use of wordplay are recapitulated below:

a. Feste is responsible for generating altogether 65 puns, which are distributed among 46 out of a total of 100 entries he makes into the stage. Accordingly, punning passages, many of which contain more than a single instance of wordplay, account for almost 50\% of the jester's entire dramatic text, which appears to make him a habitual punster and his play with words a character-defining feature. ${ }^{15}$

b. Feste pits his wits against all central characters in TN, yet playful responses to his wordplay are sporadic.

c. As far as the subject-matter of his punning is concerned, the only recurring play is that on the word fool which, carrying a double meaning (namely 'a jester' and 'a simpleton'), appears to be intended not only as a meta-commentary on the profession of jester but also as a foil for human folly. The two meanings are put to playful use altogether 14 times by Feste, and their interplay assumes mostly the form of highly elaborate punning patterns.

d. An assaultive use of puns on the word fool in all participant configurations evidences firmly that the jester does not attempt to carefully tailor his wordplay to the type of interacting party, and is, in effect, as impertinent in exchanges with low characters as in those with his betters.

e. The jester rarely engages in lengthy punning interactions; instead, his wordplay assumes for the most part the form of short, brilliant repartees scattered throughout the play.

While, due to lack of terminological rigour, Feste's role may be confused with Costard's ( $L L L)$ and Lance's (TGV), country rustics, the wordplay practiced

15 Interestingly, Feste's non-punning lines involve various wordplay-related phenomena (e.g. rhyme) as well as frequent manifestations of extra-linguistic humour, principally the wit of ideas. 
by the two categories of characters is substantially different in that the jester puns consciously, purposefully and caustically. At the same time, a close parallel can be drawn between his punning and a playful use of language by pages (e.g. Moth in $L L L$ and Speed in $T G V$ ), whose wit is equally sparkling.

\section{REFERENCES}

Adamczyk, M. 2010. "Shakespeare's wordplay gender-wise: Punning as a marker of male-female relationships". Topics in Shakespeare's English. Eds. P. Kakietek and J. Nykiel. Częstochowa: Wydawnictwo Wyższej Szkoły Lingwistycznej. 185-199.

Calvo, C. 1991. Power Relations and Fool-Master Discourse in Shakespeare: A Discourse Stylistics Approach to Dramatic Dialogue. Nottingham: Department of English Studies, University of Nottingham.

Chiaro, D. 1992. The Language of Jokes: Analysing Verbal Play. The Interface series. New York, London: Routledge.

Culler, J. 1988. "The call of the phoneme: Introduction". On Puns: The Foundation of Letters. Ed. J. Culler. Oxford: Basil Blackwell. 1-15.

Delabastita, D. 1993. There's a Double Tongue: An Investigation into the Translation of Shakespeare's Wordplay with Special Reference to Hamlet. Approaches to traslation Studies II. Amsterdam, Atlanta, GA: Rodopi.

Ellis, H. A. 1973. Shakespeare's Lusty Punning in Love's Labour's Lost: with Contemporary Analogues. Studies in Enlgish Literature 81. The Hague, Paris: Mouton.

Esar, E. 1954. The Humor of Humor: The Astand Techniques of Popular Comedy Illustrated by comic sayings, Funny Stories, and Secular Traditions throught the Centuries. London: Phoenix House.

Freidhof, G. 1984. "Zur Typologisierung von Wortspielen mit Hilfe von oppositiven Merkmalen". Slavistische Linguistik 1983: Referate des IX. Konstanzer Slavistischen Arbeitstreffens. Slavistische Beiträge 181. Ed. P. Rehder. München: Otto Sagner. 9-37.

Hausmann, F. J. 1974. Studien zu einer Linguistik des Wortspiels: Das Wortspiel im Canard Enchaîné. Beihefte zur Zeitschrift für Romanische Philologie 143. Tübingen: Max Niemeyer Verlag.

Heibert, F. 1993. Das Wortspiel als Stilmittel und Seine Übersetzung: Am Beispiel von Sieben Übersetzungen des Ulysses von James Joyce. Tübingen: Gunter Narr Verlag. 
'BETTER A WITTY FOOL THAN A FOOLISH WIT': ON PUNNING STYLES OF SHAKESPEARE'S...

Heller, L. G. 1974. "Toward a general typology of the pun”. Language and Style 7: 271-282.

Herman, V. 1995. Dramatic Discourse: Dialogue as Interaction in Plays. London, New York, NY: Routledge.

Hill, A. A. 1988. "Chaucer and the pun-hunters: Some points of caution". On Language: Rhetorica, Phonologica, Syntactica. A Festschrift for Robert P. Stockwell from His Friends and Colleagues. Eds. C. Duncan-Rose, J. Fisiak and T. Vennemann. London, New York, NY: Routledge. 66-78.

Kohl, N. 1966. Das Wortspiel in der Shakespeareschen Komödie: Studien zur Interdependenz von Verbalem und Aktionalem Spiel in den Frühen Komödien und den Späten Stücken. Unpublished Ph.D. thesis. Johann Wolfgang Goethe-Universität: Frankfurt am Main.

Kökeritz, H. 1953. Shakespeare's Pronunciation. New Haven, CT: Yale University Press.

Mahood, M. M. 1957. Shakespeare's Wordplay. University Paperbacks UP 242. London, New York: Methuen \& Co. Ltd.

Onions, C. T. 1919. A Shakespeare Glossary. Oxford: Clarendon Press.

Redfern, W. 1984. Puns: Language Library. Oxford, New York NY: Basil Blackwell.

Schlauch, M. 1959. The English Language in Modern Times (since 1400). Warszawa: Państwowe Wydawnictwo Naukowe.

Shakespeare, W. 1951. Love's Labour's Lost. Ed. R. D. David. The Arden Shakespeare. London: Methuen and Co. Ltd.

Shakespeare, W. 1988. Twelfth Night. Ed. E. S. Donno. The New Cambridge Shakespeare. Cambridge: Cambridge University Press.

Szczerbowski, T. 1998. Gry Jezykowe w Przektadach Ulissesa Jamesa Joyce'a. Kraków: Polska Akademia Nauk.

West, G. 1998. A Dictionary of Shakespeare's Semantic Wordplay. Studies in Renaissance Literature. Lewiston, NY: The Edwin Mellen Press.

Wurth, L. 1895. Das Wortspiel bei Shakspere. Wien, Leipzig: Wilhelm Braumüller. 